\title{
Induced Breeding of Butter Catfish Ompok bimaculatus Using Developed Portable FRP Pabda Hatchery for Seed Production
}

\author{
Ajmal Hussan, Bikash Chandra Mohapatra*, Arabinda Das, \\ Partha Pratim Chakrabarti, Dukhia Majhi, Sandip Kumar Panda, \\ Subhendu Adhikari and Bindu Raman Pillai
}

\author{
Regional Research Centre, ICAR-Central Institute of Freshwater Aquaculture, Rahara, \\ Kolkata- 700118, West Bengal, India \\ ICAR-Central Institute of Freshwater Aquaculture, Kausalyaganga, Bhubaneswar-751002, \\ Odisha, India \\ *Corresponding author
}

\section{A B S T R A C T}

\begin{tabular}{|l|}
\hline Ke y w o r d s \\
Butter catfish, \\
Ompok \\
bimaculatus, Pabda, \\
FRP, Portable \\
pabda hatchery, \\
Pabda breeding, \\
Seed production \\
\hline Article Info \\
\hline $\begin{array}{l}\text { Accepted: } \\
\text { 18 May } 2020 \\
\text { Available Online: } \\
\text { 10 June } 2020\end{array}$ \\
\hline
\end{tabular}

\section{Keywords}

Butter catfish, Ompok

bimaculatus, Pabda, RP, Portable

Article Info

18 May 2020

10 June 2020
Portable Fiberglass Reinforced Plastic (FRP) pabda hatchery consisting of three incubation pools and three rearing tanks having capacity to accommodate about 45,000 - 50,000 nos. fertilized eggs and to produce about 10,000 - 15,000 nos. of early fry of Ompok bimaculatus (pabda) in a single cycle was developed, established and operated at Kalyani Field Station of RRC-Rahara of ICAR-CIFA. Four different induced breeding experiments were conducted using 14 pairs of pabda brooders (female: $120.75 \pm 39.25 \mathrm{~g}$ and male: $68.89 \pm 15.92 \mathrm{~g}$ ) in the established hatchery between August and October, 2019 using synthetic hormone Ovatide. Brooders were injected within 8-12 hrs of harvest to ensure proper acclimatization and also to avoid stress due to long time confinement. Females and males were injected with hormone @ $1.5 \mathrm{ml}$ and $0.75 \mathrm{ml}$ per kg body weight, respectively. Latency period was 8.5-10 hrs and relative fecundity ranged from 131-186 eggs/g body weight of female. Rate of fertilization achieved was $72.57 \pm 6.62 \%$ at water temperature range of $25-27^{\circ} \mathrm{C}$. Fertilized eggs were distributed in the FRP incubation pools and maintained for hatching in two different flow-through systems (feeble water circulation + aeration, and feeble water shower + aeration). Eggs hatched out between 22-27 hrspost fertilization (hpf) at water temperature of $26.67 \pm 1.58^{\circ} \mathrm{C}$, with no clear difference between the two systems. Though not statistically significant, average rate of hatching were observed little higher in system with feeble water shower and aeration $(65.25 \pm 7.71 \%)$ than feeble water circulation and aeration $(64.20 \pm 9.47 \%)$. Yolk-sac of newly hatched larvae (measured $3.8-4.5 \mathrm{~mm}$ in length) got absorbed within $60 \mathrm{hpf}$. A total of approximately 43,000 nos. seeds after 7 days of hatching with hatchlings survival rate of 43.8 to $58.5 \%$ were achieved.

\section{Introduction}

Aquaculture is the fastest growing food producing sector and by 2025 , one out of every two fish eaten may come from aquaculture (Bartley, 2005). Diversification of the aquaculture species and systems is one of the key approaches that provide enormous 
scope to achieve that goal. The butter catfish, Ompok bimaculatus (Bloch, 1794), colloquially known as 'Pabda' is one of the indigenous fish of Indian sub-continent, prioritized in recent time in India for freshwater aquaculture diversification because of its high delicacy and high market price, particularly in eastern and north-eastern parts of India. This fish occurs naturally in streams, rivers, canals, bheels, Jheels and reservoirs, and breeds naturally in large water bodies particularly in flowing rivers. But due to indiscriminate fishing, habitat destruction, pollution and various other ecological changes in its natural habitats, wild population of this species including availability of its seeds has declined steadily, and now globally categorized as near threatened (IUCN, 2019), but enlisted as endangered in India (CAMP, 1998). In order to meet the demand and also to reduce pressure on natural stocks, so far good number of works has been attempted on induced breeding of this species, and achieved varied degree of success (Parameswaran et al., 1970; Sridhar et al., 1998; Debnath et al., 2013). But due to high mortality rate of larvae during larval rearing, seed supply of this species is not at par with the demand for commercial production of this species. Moreover, there is also no designated hatchery for breeding of this species and so far most of the breeding attempts for the species have been conducted using flowthrough tub system or by using hatcheries and structures designated for breeding of other fish species (Sridhar et al., 1998; Debnath et al., 2013).

The AICRP on Plasticulture Engineering and Technology (PET), centre at ICAR-Central Institute of Freshwater Aquaculture, Bhubaneswar designed and developed a portable hatchery fully made up of fibreglass reinforced plastics (FRP) for induced seed production of pabda. The hatchery has several benefits viz., it is portable, easy to install and operate, requires less quantity of water during fish breeding and spawn production, needs less space for installation and durable for about fifteen years. The system has two major parts: i) Incubation unit, having capacity to accommodate 45,000 - 50,000 nos. fertilized eggs in one operation, and ii) Rearing unit, using which 10,000 - 15,000 nos. of early fry of $O$. bimaculatus can be produced in a single operation. Moreover, rearing unit can also be used for acclimation of brooders after harvest and nurturing of injected brooders during latency period.

\section{Materials and Methods}

\section{FRP pabda hatchery unit}

Portable FRP Pabda hatchery unit consisting of three major parts, i.e., incubation unit consisting of three pools (Fig. 1), rearing unit consisting of three tanks and one overhead water storage tank of capacity 1000-1500 L was installed at Kalyani Field Station, West Bengal under RRC-Rahara of ICAR-CIFA for operation and seed production.

\section{Incubation unit}

Three cylindro-vertical hatching/incubation pools are placed one above other on a triangular iron frame to minimize requirement of space. The pools of the incubation unit are also so designed that, one fit inside other, for ease of transportation. Diameter of largest pool is $1.2 \mathrm{~m}$ and $1.0 \mathrm{~m}$ for smallest pool and height of each is $0.20 \mathrm{~m}$. One inner chamber and four RPVC duck-mouths are fitted at the bottom for circulation of the eggs with feeble water current or keep eggs in suspension in water, as per need. A water shower is also provided on the top margin of the pool to provide option of water showering as per need. Drainage outlet is fitted at the centre for draining and cleaning purposes and also for 
hatchlings collection. The system is suitable for incubation of 45,000 - 50,000 nos. fertilized eggs in a single operation.

\section{Rearing Unit (Brood acclimation-cum- Latency stage nurturing-cum-Hatchling rearing tanks)}

Three rectangular tanks of different sizes were designed for using multiple purposes, $v i z$, for acclimation of pabda brood fish after collection; for nurturing of brooders during latency period after injecting inducing hormone; and for rearing of hatchlings to early fry stage. Size of largest tank is $3.0 \times 1.1$ $\mathrm{x} 0.60 \mathrm{~m}$ and smallest is of $2.8 \times 0.9 \times 0.6 \mathrm{~m}$; to allow fittings of one inside another during transportation. For maintaining water level based on purpose of use, outlets fitted with individual full-way valves are provided. The system is suitable for acclimation of $8-10 \mathrm{~kg}$ brooders of pabda and also for nurturing of injected brooders of 5-6 kg. The system can also be used for rearing of hatchlings and about $10,000-15,000$ nos. of early fry can be produced in a single cycle.

\section{Water supply and aeration system}

One plastic overhead water storage tank of capacity 1000litre is installed near the hatchery unit to supply water for hatchery operation. Supply lines from it are connected with the incubation pools and rearing tanks. An air pump is also fitted for sufficient supply of oxygen to the hatchery, particularly to the rearing unit.

\section{Brood stock management}

Adult fishes of $O$. bimaculatus were stocked@ 20,000 nos. ha ${ }^{-1}$ in a 0.10 ha pond having water depth of $1.2 \mathrm{~m}$ during the month of May, 2019 at Kalyani Field Station of ICAR-CIFA. Before stocking pond was prepared following standard methods of pre- stocking management (liming @ $300 \mathrm{~kg} \mathrm{ha}^{-1}$ and basal fertilization using cowdung @ 4,000 kg ha ${ }^{-1}$ and single super phosphate @ $40 \mathrm{~kg} \mathrm{ha}^{-1}$ ) and after stocking intermittent fertilizations were carried out in every 15 days interval with cow dung at $500 \mathrm{~kg} \mathrm{ha}^{-1}$ and SSP @ $20 \mathrm{~kg} \mathrm{ha}^{-1}$ to maintain the pond fertility. A floating island prepared with Eichhornia covering $10 \%$ of the water surface area was provided as hide-outs for the fishes, which also helped in keeping temperature of the pond under control. To ensure sufficient oxygen in the brood rearing pond, aeration was provided for at least 3 hours daily using a paddle-wheel aerator. Brood fishes were fed with commercial floating pellets having crude protein $\geq 32 \%$.

\section{Inducing agent}

Ovatide, an indigenous, cost-effective hormonal formulation developed by Mumbaibased pharmaceutical company, M/s Hemmo Pharma was used for the breeding programmes. Ovatide is easy to store at room temperature, simple to use and less expensive (CIFE, 1997) and has been successfully tested for ovulation of several fishes, including major carps like Catla catla, Labeo rohita (Chakrabarti et al., 2017), minor carps like Puntius sarana (Udit et al., 2014) and catfishes like Clarias batrachus (Jagtap and Kulkarni, 2015) in India.

\section{Breeding programme}

Four breeding experiments $\left(\mathrm{T}_{1}: 4^{\text {th }}\right.$ quarter of August, 2019; $\mathrm{T}_{2}: 2^{\text {nd }}$ quarter of September, 2019; $\mathrm{T}_{3}: 4^{\text {th }}$ quarter of September, 2019; $\mathrm{T}_{4}$ : $2^{\text {nd }}$ quarter of October, 2019) were conducted using the FRP pabda hatchery installed at Kalyani Field Station of ICAR-CIFA during August-October, 2019. Matured male (22.82 $\pm 1.92 \mathrm{~cm} / 68.34 \pm 14.37 \mathrm{~g})$ and female $(25.38$ $\pm 2.37 \mathrm{~cm} \mathrm{/} 120.83 \pm 39.40 \mathrm{~g})$ of $O$. bimaculatus, free from diseases and any kind 
of abnormalities, were selected for the breeding programme based on morphological characters like swollen abdomen, pinkish vent and smooth pectoral fin in female; and rough pectoral fin in mature male. Brooders were then carefully transferred to the rearing unit (tanks) of the pabda hatchery avoiding much handling and conditioned for $4 \mathrm{hrs}$ with sufficient aeration prior to administration of inducing agent, Ovatide. Male and female brooders were injected @ $0.75 \mathrm{ml} / \mathrm{kg}$ and 1.5 $\mathrm{ml} / \mathrm{kg}$ body weight, respectively, into the muscular basal part of the dorsal fin the fish in a single dose. The injected fishes were then maintained in the rearing unit of the hatchery with sufficient aeration and mild water sprinkle during latency period. Females were stripped and eggs were collected after 8.5-10 hrs of hormonal injection. Testes from males were removed surgically and then milt from testes was squeezed over the eggs. Then eggs and milt were mixed together usinga feather for their fertilisation. The eggs were then washed thoroughly with clean water and transferred into the incubation pools of the FRP pabda hatchery unit. Fertilized eggs were spread uniformly in the floor of the incubation pools of the hatching/incubation unit and kept with feeble water shower along with aeration $\left(\mathrm{C}_{1}\right)$ or feeble water circulation along with aeration $\left(\mathrm{C}_{2}\right)$. Each pool was provided with an outlet as a height of six $\mathrm{cm}$ to maintain desired water level and drain out excess water.

\section{Estimation of fecundity, fertilization and hatching rate}

Absolute fecundity, relative fecundity, fertilization rate and hatching rate were recorded (taking random samples) to determine the effectiveness of breeding programs. Absolute fecundity (AF) of each female was calculated after collecting sample from spawned oocytes and using the formula: $\mathrm{AF}=\mathrm{NOG} \times \mathrm{OW}$, where $\mathrm{NOG}=$ number of oocytes per gram of the sample and $\mathrm{OW}=$ total weight of spawned oocytes. Relative fecundity (RF) was also estimated by the formula: $\mathrm{RF}=\mathrm{AF} / \mathrm{BW}$, where $\mathrm{AF}=$ absolute fecundity, $\mathrm{BW}=$ body weight. For determination of fertilization rate and hatching rate five samples from each batch were collected randomly and then estimated by using the following formulae:

Fertilization rate $(\%)=$

Number of fertilized eggs

Total no of eggs in sample [Fertilized + unfertilized]

Hatching rate $(\%)=$

Number of hatchlings (after $12 \mathrm{hr}$ post first hatchling observed)

Total number of fertilized eggs

\section{Analysis of water quality parameters}

The water quality indices of all the experimental pools and tanks were monitored on every alternate day during the breeding operation. Water quality indices of brood stock pond were recorded weekly. Water temperature, $\mathrm{pH}$, TDS, ORP, turbidity and conductivity were measured using digital water quality analyser. Dissolved oxygen, alkalinity, hardness, phosphate and nitrite were determined following the standard procedures described in APHA (2012) and expressed in $\mathrm{mg} / \mathrm{l}$.

\section{Analysis of experimental data}

All data are presented as mean \pm standard deviation. The data were analysed by one-way analysis of variance (ANOVA) using SPSS 16.0 for Windows (SPSS Inc., Chicago, IL, USA), to find out whether any significant difference $(\mathrm{P}<0.05)$ existed among treatment means (Duncan 1955). 


\section{Results and Discussion}

Matured $O$. bimaculatus given with single injection of Ovatide were successfully induced bred four times during the month of August-October, 2019 using developed portable FRP pabda hatchery. Results of the experiments have been summarized in Table 1. Though many authors suggested simple systems like plastic tubs, aquaria, cemented tanks, hapa, etc. for egg incubation, as well seed rearing of pabda (Debnath et al., 2013; Pradhan and Barman, 2014; Hossain et al., 2017), no palpable unit for seed production of pabda through induced breeding is available. Portable fiberglass reinforced plastic (FRP) made pabda hatchery designed and developed by AICRP on PET, ICAR-CIFA has added a feather towards meeting the increasing demand of the seed of this high-value catfish. This is first time a dedicated FRP hatchery unit for pabda has been developed and four successful trials of induced breedings were achieved. For breeding trials, brooders were collected from a well maintained brood fish pond with a ratio of 1:1 (M:F). Water quality parameters recorded in the brood pond during the period from May to October are shown in Table 2, and found well within the permissible range.

Brood male of 1 year+ with average weight of $68.89 \pm 15.92 \mathrm{~g}$ and female of 1.5 year+ having weight $120.75 \pm 39.26 \mathrm{~g}$ were selected, as $O$. bimaculatus generally become mature at the end of first year of its life (Qayyum and Qasim, 1964).O. bimaculatus were successfully induced bred during present study by injecting males and females with synthetic hormone Ovatide @ $0.75 \mathrm{ml}$ and 1.5 per $\mathrm{kg}$ body weight, respectively. Sridhar et al.(1998) reported successful induced breeding of this fish using Ovaprim @ 0.5 $\mathrm{ml} / \mathrm{kg}$ of body weight in both males and females. Debnath et al., (2013) also induced bred the fish successfully using Ovaprim per $\mathrm{kg}$ body weight of male and female at a dosage of $0.5-1.0 \mathrm{ml}$ and 1-1.5 $\mathrm{ml}$, respectively. Latency period of the fishes not varied significantly across the trials and were in the range of 8.5-10 hrs, at temperature range of 26.5 to $30{ }^{\circ} \mathrm{C}$ (Table 3). Raizada et al., (2013) also reported 7-8 hrs of latency period for $O$. bimaculatus at temperature $27 \pm$ $0.5{ }^{\mathrm{O}} \mathrm{C}$ and induced using sGnRH analogue and dopamine antagonist @ $0.7 \mathrm{ml} \mathrm{kg}^{-1}$ body weight for female and $0.5 \mathrm{ml} \mathrm{kg}^{-1}$ for male. Absolute fecundity recorded during present study was in the range of 12,870 to 20,824 eggs/fish. Absolute fecundity range recorded during the study was small compared to the report of the other authors (Rao and Karamchandani, 1986; Arthi et al., 2013), mainly because of the comparable size (weight: $85-152 \mathrm{~g}$ ) and maturity stage of the females. Relative fecundity in the range of 131-186 eggs/g body weight of female recorded during present study was low compared to $221 \mathrm{eggs} / \mathrm{g}$ of body weight of female of the species reported by Parameswaran et al., (1970).

Fertilization was recorded in the range of 59$82 \%$ at water temperature range of $25-27^{\circ} \mathrm{C}$. No significant difference in fertilization rate was observed till last week of September, but reduced significantly to about $63 \%$ in October, may be because of the beginning of follicular atresia coupled with other extrinsic factors. Eggs were kept in two different types of flow-through systems, viz., feeble water shower and aeration $\left(\mathrm{C}_{1}\right)$ and feeble water circulation and aeration $\left(\mathrm{C}_{2}\right)$. Eggs hatched out between 22-27 hrs post fertilization (hpf) at water temperature of $26.67 \pm 1.58^{\circ} \mathrm{C}$. Though no clear statistically significant difference between the two systems were observed (Fig. 2), overall rate of hatching were found little higher in $\mathrm{C}_{1}(65.25 \pm 7.71 \%)$ than $\mathrm{C}_{2} \quad(64.20 \pm 9.47 \%)$. No significant differences in hatching rate among the treatment were observed. 
Table.1 Results of induced breeding experiments of $O$. bimaculatus

\begin{tabular}{|c|c|c|c|c|c|}
\hline \multirow[t]{2}{*}{ Parameters } & \multicolumn{4}{|c|}{ Experiment } & \multirow[t]{2}{*}{ Overall } \\
\hline & $\mathrm{T} 1$ & $\mathrm{~T} 2$ & $\mathrm{~T} 3$ & $\mathrm{~T} 4$ & \\
\hline No. of brooder pairs & 03 & 04 & 04 & 03 & 14 \\
\hline Weight of female (g) & $120.83 \pm 20.25$ & $100.87 \pm 20.20$ & $101 \pm 6.33$ & $128 \pm 31.74$ & $120.75 \pm 39.26$ \\
\hline Ovatide dosage (ml/kg body weight) & 1.5 & 1.5 & 1.5 & 1.5 & 1.5 \\
\hline Weight of male (g) & $75.12 \pm 6.30$ & $57 \pm 5.63$ & $53.66 \pm 5.50$ & $71.87 \pm 13.02$ & $68.89 \pm 15.92$ \\
\hline Ovatide dosage (ml/kg body weight) & 0.75 & 0.75 & 0.75 & 0.75 & 0.75 \\
\hline Latency period (hr) & $8.90 \pm 0.30^{\mathrm{a}}$ & $9.10 \pm 0.30^{\mathrm{a}}$ & $9.10 \pm 0.25^{\mathrm{a}}$ & $9.60 \pm 0.35^{\mathrm{a}}$ & $9.20 \pm 0.40$ \\
\hline Absolute fecundity (no.) & $16728 \pm 1389^{a}$ & $15105 \pm 1836^{\mathrm{ab}}$ & $15729 \pm 1663^{\mathrm{a}}$ & $18749 \pm 1880^{\mathrm{ac}}$ & $16568 \pm 2127$ \\
\hline Relative fecundity (no.) & $140.66 \pm 15.89^{\mathrm{a}}$ & $151.75 \pm 17.54^{\mathrm{a}}$ & $156 \pm 19.42^{\mathrm{a}}$ & $149.50 \pm 20.95^{\mathrm{a}}$ & $150.10 \pm 17.52$ \\
\hline Fertilization rate $(\%)$ & $77.67 \pm 3.51^{\mathrm{a}}$ & $76.50 \pm 3.87^{\mathrm{a}}$ & $72 \pm 3.36^{\mathrm{a}}$ & $63.33 \pm 4.51^{b}$ & $72.57 \pm 6.62$ \\
\hline Hatching rate $(\%)$ & $69.67 \pm 7.09^{\mathrm{a}}$ & $64.50 \pm 5.32^{\mathrm{a}}$ & $66.75 \pm 8.73^{\mathrm{a}}$ & $59.33 \pm 4.04^{\mathrm{a}}$ & $65.14 \pm 6.91$ \\
\hline $\begin{array}{l}\text { Hatchlings survival rate after } 7 \text { days } \\
(\%)\end{array}$ & $47.66 \pm 3.05^{\mathrm{a}}$ & $58.50 \pm 8.11^{\mathrm{a}}$ & $45.75 \pm 5.85^{\mathrm{a}}$ & $43.66 \pm 5.51^{\mathrm{a}}$ & $49.35 \pm 8.18$ \\
\hline
\end{tabular}


Table.2 Physico-chemical characteristics of broodstock pond of $O$. bimaculatus

\begin{tabular}{|l|l|}
\hline Parameters & Value $($ Mean \pm SD) \\
\hline Temperature & $30.28 \pm 1.07^{\circ} \mathrm{C}$ \\
\hline pH & $7.72 \pm 0.32$ \\
\hline Turbidity & $33.67 \pm 2.08 \mathrm{FNU}$ \\
\hline Conductivity & $632.33 \pm 8.51 \mu \mathrm{S} / \mathrm{cm}$ \\
\hline ORP & $237 \pm 3.61 \mathrm{mV}$ \\
\hline TDS & $405.67 \pm 9.07 \mathrm{mgl}^{-1}$ \\
\hline Dissolved Oxygen & $6.62 \pm 0.21 \mathrm{mgl}^{-1}$ \\
\hline Total Alkalinity & $212.67 \pm 5.03 \mathrm{mgl}^{-1}$ \\
\hline Total Hardness & $229.61 \pm 6.03 \mathrm{mgl}^{-1}$ \\
\hline Phosphate & $0.19 \pm 0.008 \mathrm{mgl}^{-1}$ \\
\hline Nitrite & $0.02 \pm 0.003 \mathrm{mgl}^{-1}$ \\
\hline
\end{tabular}

Table.3 Water quality parameters during the breeding experiments

\begin{tabular}{|l|l|}
\hline Parameters & Value $($ Mean \pm SD) \\
\hline Temperature & $27.29 \pm 1.78^{\mathrm{O}} \mathrm{C}$ \\
\hline pH & $7.41 \pm 0.22$ \\
\hline Turbidity & $22.54 \pm 1.34 \mathrm{FNU}$ \\
\hline Conductivity & $285.81 \pm 3.83 \mu \mathrm{S} / \mathrm{cm}$ \\
\hline ORP & $180.6 \pm 3.36 \mathrm{mV}$ \\
\hline TDS & $142.29 \pm 3.51 \mathrm{mgl}^{-1}$ \\
\hline Dissolved oxygen & $7.42 \pm 0.18 \mathrm{mgl}^{-1}$ \\
\hline Total Alkalinity & $153.33 \pm 6.11 \mathrm{mgl}^{-1}$ \\
\hline Total Hardness & $172.66 \pm 4.45 \mathrm{mgl}^{-1}$ \\
\hline
\end{tabular}


Fig.1 Cylindro-vertical incubation unit of the FRP Pabda hatchery

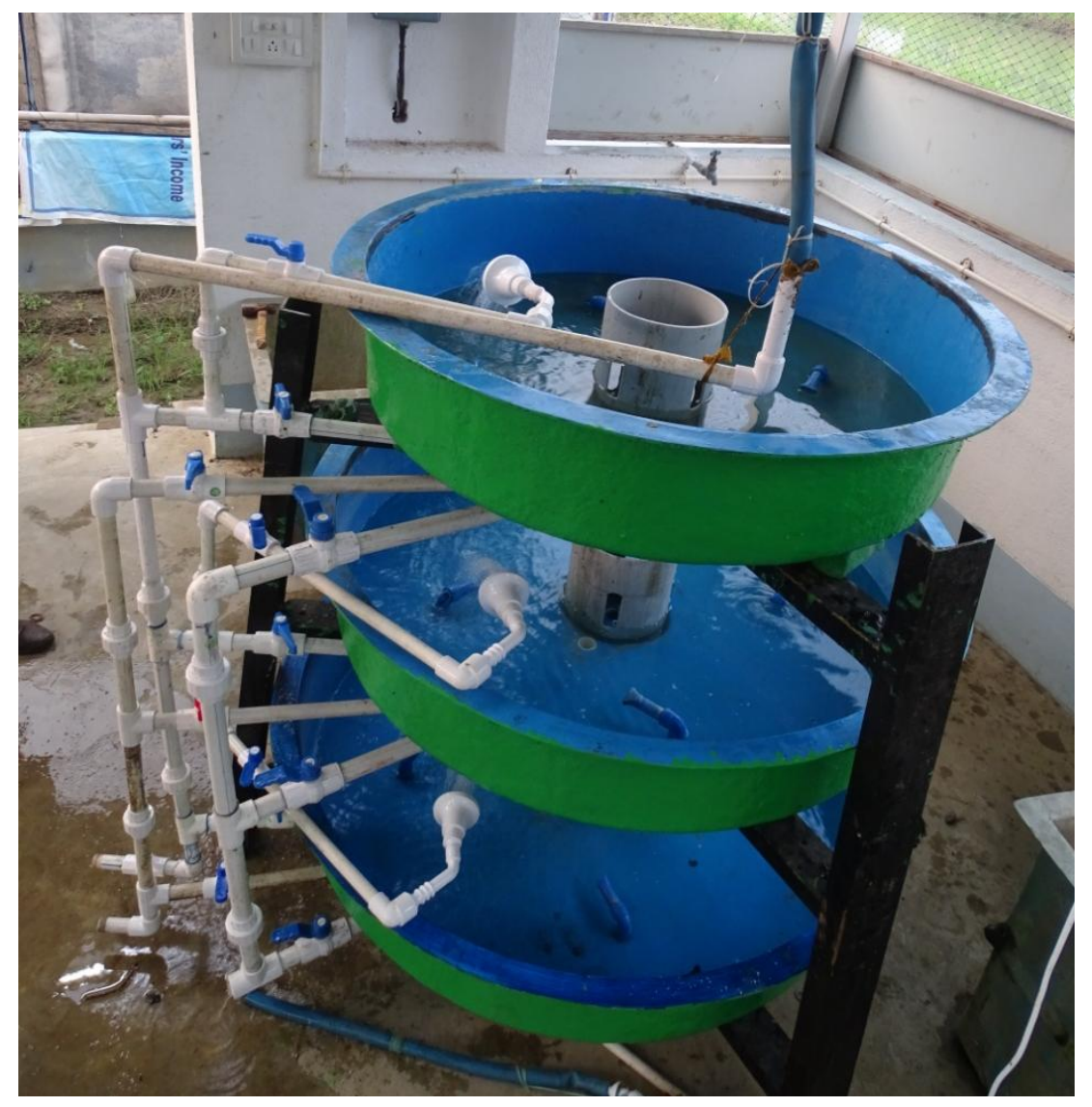

Fig.2Comparison of hatching rate in different flow-through systems

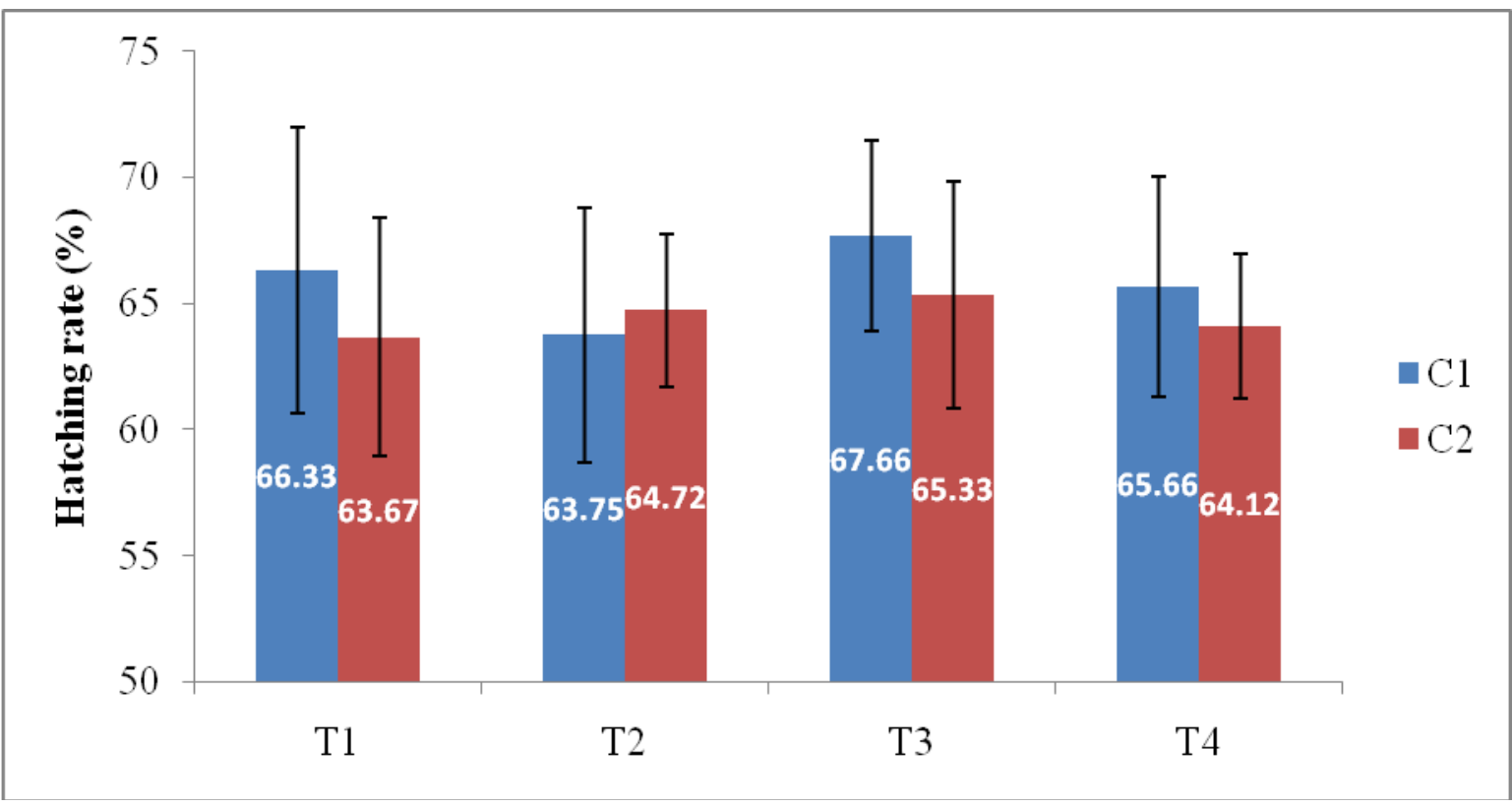

(C1 = egg incubation with feeble water shower and aeration;

$\mathrm{C} 2$ = egg incubation with feeble water circulation and aeration) 
Fertilization rate in the range of $54-77 \%$ observed during present study is comparable with findings of Chaturvedi et al., (2013), who reported 70-80\% hatching success of O.bimaculatus in flow-through hatchery. Though Raizadaet al., (2013) reported 80$90 \%$ hatching rates for O. bimaculatus in flow-through hatchery, hatching time of $21 \pm$ $1 \mathrm{hpf}$ at $27 \pm 0.5^{\circ} \mathrm{C}$ reported by them is comparable with our findings. Yolk-sac of newly hatched larvae was found to get absorbed completely within 60 hpf compare to $48 \mathrm{hpf}$ time for yolk-sac absorption for the same species reported by Raizada et al., (2013). Size of hatchlings measured $3.8-4.5$ $\mathrm{mm}$ in total length during present study was greater than hatchling size of $2.5 \pm 0.1 \mathrm{~mm}$ in total length for same species reported by Raizada et al., (2013). The survival rate of $O$. bimaculatus larvae in the present experiment were in the range of $43.8-58.5 \%$ after 7 days of hatching. Though not statistically quite significant, the average rate of survival was found highest during $2^{\text {nd }}$ quarter of September $\left(\mathrm{T}_{2}\right)$ compared to all other treatments, may be linked with the less number of shooters that observed in $\mathrm{T}_{2}$ compared to all other treatments. As food type and feeding schedule and all other practices including provision of hiding places across the treatments were same, concluding a reason behind the less number of shooters in $\mathrm{T}_{2}$ is difficult. But, across the treatments larval survival rate after 7 days of hatching observed during present study was significantly higher than larval survival of $10.4 \%$ after 10 days rearing reported by Raizada et al., (2013).

Results of the experiments typify the efficiency and effectiveness of the FRP Pabda hatchery for induced breeding of $O$. bimaculatus. Besides the hatchery is easy to transport and install, needs less space for installation and expected to be durable for about fifteen years, like FRP carp hatchery (Mohapatra et al., 2005). Considering these positives of the hatchery and its successful trials for seed production of $O$. bimaculatus, we can expect that the hatchery will go ahead to fulfil the demand of the seeds of this high valued delicacy and also serve as a tool to aid its conservation.

\section{Acknowledgements}

The authors are thankful to the Project Coordinator, All India Coordinated Research Project on Plasticulture Engineering and Technology, Ludhiana for funding to the project and the Director, ICAR-Central Institute of Freshwater Aquaculture, Bhubaneswar for providing logistic supports to the project.

\section{References}

APHA, 2012. Standard Methods for the Examination of Water and Wastewater (22 $2^{\text {nd }}$ ed.), American Public Health Association, Washington DC.

Arthi, T., Nagarajan, S., Vijayaraman, K. and Sivakumar, A.A. 2013.Fecundity and sex-ratio of two freshwater fishes, Ompok bimaculatus and O. malabaricus (Bloch) of the river Amaravathy, Tamil Nadu, India. The Bioscan, 8(1): 159163.

Bartley, D. M. 2005. Status of the world's fishery genetic resources. Proceedings of the International Workshop on Role of Biotechnology, March 5-7, 2005, Villa Gualino, Turin, Italy. Pp. 7-16.

CAMP, 1998. Report of the Workshop on Conservation Assessment and Management Plan (CAMP) for Freshwater Fishes of India. ZooOutreach Organization and NBFGR, Lucknow, India. p. 156.

Chakrabarti, P.P., Mohapatra, B.C., Hussan, A., Das, A., Mandal. R. N., Ghosh, A., Choudhuri, G. and Jayasankar, P. 2017. Induced breeding of carps for seed 
production in FRP hatchery. Advances in Applied Science Research, 8(1):8893.

Chaturvedi, C.S., Shukla,V.K.,Singh,R. K. and Pandey, A.K. 2013. Captive breeding and larval rearing of endangered Ompok bimaculatus under controlled condition at Raipur, Chhattisgarh (India). Biochemical and Cellular Archives, 13(1): 133-136.

CIFE, 1997. New synthetic hormone "Ovatide" for fish breeding. Central Institute of Fisheries Education, Mumbai, India. Pp. 1-25.

Debnath, C., Sahoo, L., Datta, M. and Ngachan, S. V. 2013. Ompok bimaculatus (Bloch, 1974), an emerging species for diversification of aquaculture in Tripura, North-Eastern India, Aquaculture Asia, XVIII (1): 3335.

Hossain, M. S., Ali, M. R., Rahman, M.I., Hasan, A. K. M. M., Iqbal, M. M. and Barman, S. K. 2017. Induced breeding of Ompokpabda with S-GnRHa. International Journal of Natural Sciences, 6(3):141-147.

IUCN, 2019.The IUCN Red List of Threatened

Species.https://www.iucnredlist.org

(Accessed on 25.11.2019)

Jagtap, H. S. and Kulkarni, S. S. 2015. Captive breeding of Asian catfish, Clarias batrachus by Ovatide in Marathwada region. Indian Journal of Life Sciences, 4(2):87-89.

Mohapatra, B. C., Singh, S. K., Sarkar, B. and
Sarangi, N. 2005. Portable FRP carp hatchery: An aid for rural aquaculture. Proceedings International Conference on Plasticulture and Precision Farming, November 17- 21, New Delhi, India, pp. 515-522.

Parameswaran, S., Selvaraj, C. and Radhakrishnan, S. 1970. Observations on the biology, induced breeding and cultural possibilities of Ompok bimaculatus (Bloch) in ponds. Proceedings of the National Academy of Sciences, India Section B, 40: 145-157.

Pradhan, P. K. and Barman, D. 2014.Preliminary Studies on Larval Rearing of an Endangered Fish of Northeast India, Ompok bimaculatus (Bloch) for Future Conservation. International Journal of Aquaculture, 4(10): 64-66.

Qayyum, A. andQasim, S. Z. 1964.Studies on the biology of some freshwater fishes, Part 3.Callichrousbimaculatus (Bloch).Journal of Bombay Natural History Society, 61(3):627-650.

Raizada, S., Lal, K. K., Sarkar, U. K., Varshney, P. K., Sahu, V., Yadav, K. C., Agnihotri, P., Awasthi A. and Jena, J. K. 2013. Captive breeding and embryonic development of butter catfish (Ompok bimaculatus, Bloch 1794), a threatened fish of Indian subcontinent in northern India. Proceedings of the National Academy of Sciences, India Section B: Biological Sciences, 83 (3): 333-339.

\section{How to cite this article:}

Ajmal Hussan, Bikash Chandra Mohapatra, Arabinda Das, Partha Pratim Chakrabarti, Dukhia Majhi, Sandip Kumar Panda, Subhendu Adhikari and Bindu Raman Pillai. 2020. Induced Breeding of Butter Catfish Ompok bimaculatus Using Developed Portable FRP Pabda Hatchery for Seed Production. Int.J.Curr.Microbiol.App.Sci. 9(06): 1835-1844. doi: https://doi.org/10.20546/ijcmas.2020.906.228 